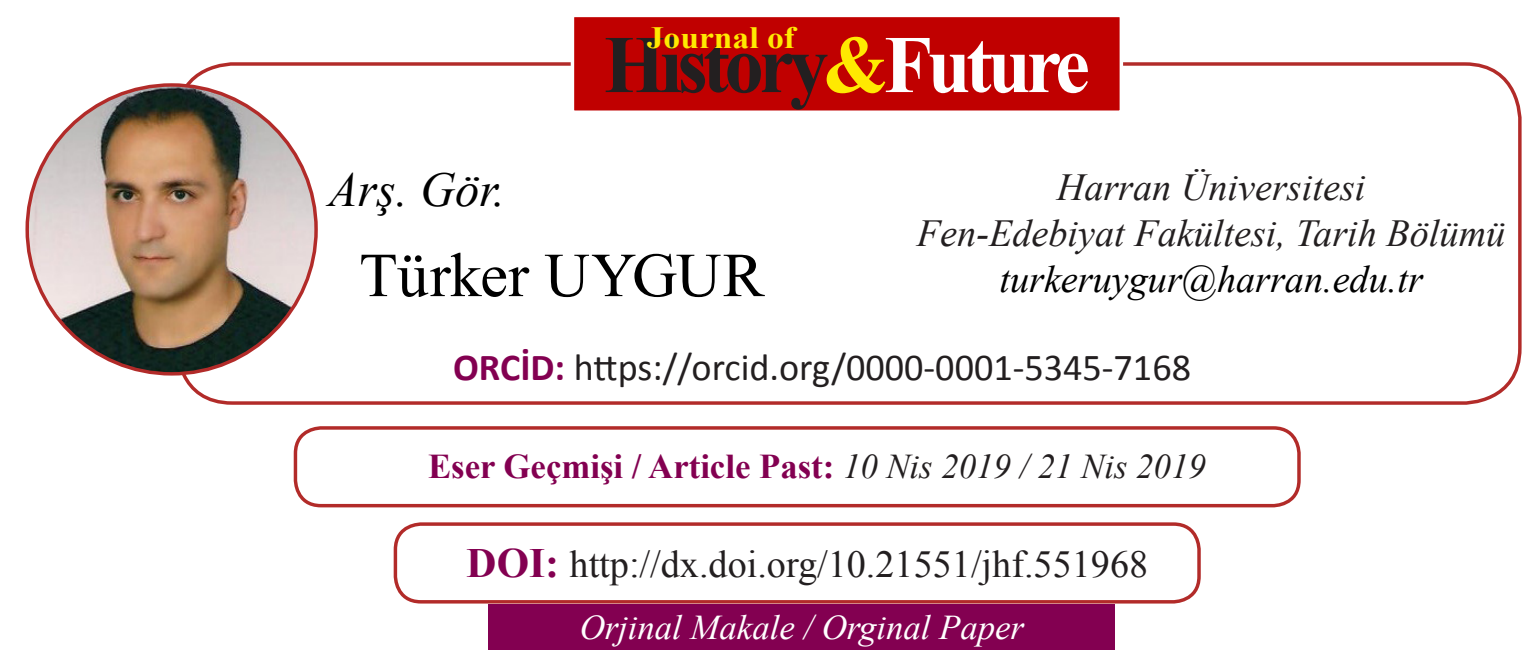

\title{
Emeviler Döneminde Fars Bölgesi ve Şiraz Şehri
}

\author{
Persian Region and City Of Shiraz During Umayyad Era
}

\section{$\ddot{\mathbf{O z}}$}

Hz. Ömer döneminde başlayan ve Hz. Osman döneminde devam eden İslam fetihleri, Hz. Ali döneminde yaşanan iç karışıklıklardan dolayı durmak zorunda kalmıştı. İslam tarihi açısından çok sıkıntılı geçen bir sürecin arkasından idareyi eline alan Emevi Hanedanı saltanat haline dönüştürdükleri idare sistemi ile İslam Devleti'ni Arap hanedan devletine dönüştürmüştür. Emevilerin bu hâkimiyet anlayışının meşru bir temele dayandırılması hakkındaki tartışmalar, bir süre sonra fetih programının devreye sokulmasıyla bir şekilde askıya alınmıştır. Böylece Emeviler, dış seferler ile hâkimiyet alanını genişleterek askeri garnizonlar kurmayı başarmıştır. Daha sonra da bölgeye Müslümanların iskân edilmesiyle yeni İslam şehirlerinin kurulması sağlanmıştır. Bu çalışmada Fars bölgesinin İslam hâkimiyetine geçişi, bölgede cereyan eden Emevi hâkimiyet mücadelelerinin yansımaları ve bir İslam şehri olarak Şiraz’ın kuruluşu konuları ele alınmıştır.

Anahtar Kelimeler: Fars Bölgesi, Şiraz, Şehir Tarihi, Emeviler

Abstract

Islamic conquests that started in Caliph Omar's era and continued during Caliph Uthman's era had to stop due to the domestic disturbances during Caliph Ali's era. The Umayyad Dynasty that took over the power after a period that had been quite troublous for the history of Islam transformed the Islamic State into an Arab dynasty state by turning the administrative system into a reign. Disputes about basing this perception of sovereignty of the Umayyad upon a legitimate ground were suspended after a while due to the conquest program put into effect. As a result, the Umayyad managed to establish military garrisons by expanding their dominance with foreign military expeditions. Then, new Islamic cities were founded by settling Muslim population into these regions. Persian region's going under Islamic rule, reflections of the power struggles of the Umayyad in the region, and the foundation of Shiraz as an Islamic city are dealt with in this study.

Key Words: Persian Region, Shiraz, City History, the Umayyad. 


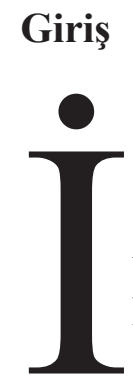

slam tarihinde Dört Halife devrinden sonra iktidar olan Muâviye ülkede siyasî istikrarı sağladıktan sonra üç farklı yönde fetih hareketlerine başlanılmıştı. Bunlar Anadolu ve Ermenistan, Horasan, Mâverâünnehir ve Sind, Kuzey Afrika bölgeleriydi. Fetih hareketlerinin düzenli bir şekilde yapılması için askeri garnizonların oluşturulması sağlanmış ve daha sonra bu garnizonlar etrafinda yeni şehirler oluşturulmuştu' ${ }^{1}$.

Askeri garnizonların daha sonra idari bir merkeze dönüşmesine bir örnek olması bakımından Şiraz, Emevi döneminin askeri hareketliliğini yansıtması açısından da güzel bir örnektir². Şiraz kurulmadan önce Fars bölgesinin merkezi konumunda olan İstahr şehri, İslam orduları tarafından uzun yıllar önce fethedilmiş olmasına rağmen, Emevi Hanedanlığı zamanında Ahameniş ve Sasani devletlerinin mirasını etkili bir şekilde yaşandığı yerlerden biridir. Bu da doğal olarak bölgeyi Mecusiler için bir merkez konumuna getirmiş ve şehirde yaşayan Mecusi sayısının her geçen gün artmasına sebep olmuştur. Bir süre sonra burada yaşayan Mecusilerin fazlalığı Müslüman Arapların kendilerini güvende hissetmemesine yol açmıştır. Bu durum, Haccâc b. Yusuf'u Irak genel valisi olarak göreve yeni başladığı yıllarda, daha sonra Şiraz adıyla anılacak olan, yeni bir şehir kurma ihtimali üzerinde düşünmeye sevk etmiş olmalıdır. Ayrıca bu yeni kurulacak şehir ile birlikte İslamiyet'i yeni kabul eden İranlıların Arapların etrafında daha güvenli bir şekilde toplanması da sağlanabilirdi ${ }^{3}$.

\section{1. Şiraz Şehrinin Kuruluşu}

Fars bölgesinin merkezi konumunda olan İstahr şehri, İslam orduları tarafindan uzun yıllar önce fethedilmiş olmasına rağmen, Emevi Hanedanlığı zamanında Ahameniş ve Sasani devletlerinin mirasını etkili bir şekilde yaşandığı yerlerden biriydi. Bu da doğal olarak bölgeyi Mecusiler için bir merkez konumuna getirmiş ve şehirde yaşayan Mecusi sayısının her geçen gün artmasına sebep olmuştur. Bir süre sonra burada yaşayan Mecusilerin fazlalığı Müslüman Arapların kendilerini güvende hissetmemesine yol açtı. Bu durum bir süre sonra Müslümanlar için bölgede yeni bir şehir kurarak kendi idarecilerinin üzerinden hâkimiyeti sağlamlaştırma ihtiyacının ortaya çıkmasına sebep oldu.

Birçok müverrihin Farsname'den rivayet ettiğine göre Halife Abdülmelik b. Mervan zamanında Haccâc, kardeşi Muhammed b. Yusuf es-Sekafî'yi H.74/M.693 yılında Fars'a göndererek orada yeni bir şehir kurmasını ve bu yeni şehrin valisi olarak oraya yerleşmesini emrettiği söylenir. Yeni kurulacak olan şehrin yeri için bölgede araştırma ve incelemelerde bulunan Muhammed $b$. Yusuf'un önceliği su kaynaklarına yakınlık ve ulaşım rahatlığı olmuştur. Muhammed b. Yusuf, bu şartlara uyan en uygun yerin İstahr yakınlarındaki antik kalıntıların bulunduğu bölgenin olduğundan emin olduktan sonra çalışmalara başlamışıır'.

1 İsmail Yiğit, “Emeviler”, Türkiye Diyanet Vakfi İslam Ansiklopedisi, TDV Yayınları, C. 11, İstanbul, 1995, s.89; Adem Apak, Ana hatlarıyla İslam Tarihi (3) (Emeviler Dönemi), Ensar Yayınları, İstanbul 2010, s.56.

2 Khalil Athamına, "Emevi Hilafeti Döneminde Arap İskanı”, Çev., Saim Yı1maz, Sakarya Üniversitesi Illahiyat Fakültesi Dergisi, S.2, Sakarya 2000, s.207.; Mustafa Zeki Terzi, "Emevîlerde Kara Ordusu Teşkilâtı”, OMÜIFD, S.9, Samsun 1997, s.48.

3 Kerametullah Efser, Tarih-i Baft-ı Kadim-i Şiraz, İntişarat-1 Encümen-i Asar ve Mefahir-i Ferhengi Yayınları, Tahran, 1353,s. 37-38.

4 İbn Belhi, Farsname, Edited by G. Le Strange, R. A. Nicholson Cambridge University Press, London, 1921, s.132; Ebu'l Abbas 
Şiraz'in kuruluşuna dair efsaneler pek çok şehrin kuruluş felsefesiyle örtüşmektedir. Zerkûb-î Şîrâzî, Haccâc'ın emri ile Fars eyaletine gelen Muhammed b. Yusuf'un burada kurulacak olan yeni şehrin yerini rüyasında gördükten sonra şehrin yerinin tespit ettiğini söylemektedir. Şîrâzî, Muhammed b. Yusuf'un rüyasını şu şekilde nakletmektedir: "Muhammed b. Yusuf, bir gece kiyafetlerini giyip uyumak için hazırlıklarını tamamladıktan sonra yatağına uzandı. Gözlerini kapatır kapatmaz rüyasına gelen melekler ona bir yer göstererek burada daire şeklinde bir şehir inşa etmesini çünkü o yerin ilerleyen yıllarda binlerce sufinin geleceği bir şehir olacağını söyledi. Ayrıca bu şehrin, buraya gelecek olan âlimlerin diğer dünyaya giderken ihtiyaç duyacaklarl her şeyin bulunduğu bir köşe olacă̆ını, fakirler için bereketli topraklar olacağını ve hikmet merkezi olmakla birlikte burada yaşayan insanların da iyi insanlar olacă̆ını söylemiştir. ",5

Muhammed b. Yusuf, uykusundan uyanır uyanmaz rüyasındaki meleklerin içine dâhil olduğu bölgeyi haritada bir daire içine alarak yeni kuracağ 1 şehrin sınırlarını belirlemiştir. Ertesi gün de İstahr'dan rüyasında gördüğü topraklara gitti ve rüyasında kendisine gösterilen bölgeyi buldu. Muhammed b. Yusuf'un Fars eyaletinin kuzey sınırlarına yakın bir bölgede bulduğu bu yer çamurlu bir arazidir. İlk bakışta çamurlu ve 1ssız topraklar olarak görünen bu topraklar çok 1şık alan güneşli bir yer olduğu için Muhammed b. Yusuf”a göre "Tur Dă̆l” gibiydi ve kutsal topraklar gibi görünmekteydi. Muhammed b. Yusuf daha sonra mühendislerini de buraya çağırarak rüyasında gördüğü şehri inşa edilmesi için hazırlıklara başlanması emrini vermiştir ${ }^{6}$.

Zerkûb-î Şîrâzî'nin naklettiğine göre, Muhammed b. Yusuf, Şiraz şehrini kurduğu gün müneccimleri çağırmış ve yıldızların Şiraz'ın geleceği hakkında ne söylediğini sormuştur. Onlarda şehri kurmak için çok uygun ve mübarek bir gün olduğunu söyleyerek bu ayın (İran takviminin altıncı ayı Sunbule ya da Şehriver ayı, ayın başak burcunda olduğu zaman) şans getireceğini söylemiştir. Hatta Merkür'ünde bu şehri olumlu yönde etkileyeceğini de sözlerine eklemişlerdir. Daha sonra Yıldızname ${ }^{7}$ adı verilen kitaplardan şehrin gelecekteki durumu hakkında bilgiler öğrenmeye çalışmışlardır ${ }^{8}$.

Ahmed b. Ebi'l-Hayr Zerkûb-i Şîrâzî, Şirazname, Nşr. Behmen Kerimi Tahran, 1305-1310, s.20-21,24; Hamdullah Müstevfi-i Kazvinî, Nuzhetü'l-Kulub, Edited by G. Le Strange, Cambridge University Press, London, 1915, s.114; Guy Le Strange, Doğu Hilafetinin Memleketleri (Mezopotamya, Iran ve Orta Asya) İslam Fetihlerinden Timur Zamanina Kadar, Trc. Adnan Ekikurt, Cengiz Tomar, Yeditepe Yayınları, İstanbul, 2015, s.314; Efser, Tarih-i Baft-ı Kadim-i Şiraz, s.27; Abdu'r-Refi Hekikat (Ref'i), Ferheng-i Tarih ve Coğrafya-yı Şehristanha-yı İan, Tahran, 1376, s.351; Mesud Keyhan, Cografyâ-yı Mufassal-ı Îrân, C.2, Tahran, 1311, s.218; John Limbert, Shiraz In The Age Of Hafez The Glory Of A Medieval Persian City, Universiy of Washington Press, Seattle, 2004, s 4; Osman Gazi Özgüdenli, "Şiraz", Türkiye Diyanet Vakfi İslam Ansiklopedisi, TDV Yayınları, C.39, İstanbul, 2010, s.182.

5 Zerkûb-i Şîrâzî, Şirazname, s.21-22; Efser, Tarih-i Baft-ı Kadim-i Şiraz, s.35-36.

6 Zerkûb-i Şîrâzî, Şirazname, s.21-22; Efser, Tarih-i Baft-ı Kadim-i Şiraz, s.35-36.

7 Yıldızların konum ve hareketlerinin bir işaret sistemi oluşturduğuna ve bu sayede insan hayatının evrelerinin bilinebileceği iddiasından hareketle yazılan kitaplardır. Arapların ilmü’t-tenciy ya da ahkâmi’n-nücum dedikleri bu inanışı batılılar astroloji olarak adlandırmıştır. Türklerde ise müneccimlik, yıldız falı ve yıldız bakıcılığı olarak bilinir. Yıldız falına bakılmak üzer yazılmış kitaplara ise "yıldızname" ismi verilmektedir. En çok kullanım şekillerinden ilki Mevâlid yani insanın doğumu sırasında burçlar kuşağındaki yıldızın konumuna bakarak geleceğe dair tahminlerde bulunmaktır. İkincisi ise İhtiyarat yani bir işe uğurlu uğursuz vakitlerin saylarını seçerek başlamaktır. Yıldıznâmelerde yedi gezegen, on iki kamerî ay ve on iki burcun esas alındığı bir sistemden bahsedilir. Yıldıza bakanın görevi yıldızına baktıranla gök cisimleri arasındaki gizli ilişkiyi bulmaktır. Bu hükümlerin yazıldığı kitaplar Büveyhi hükümdarı Azaduddevle zamanına kadar varlıklarını yoğun bir şekilde sürdürmüş daha sonraları ortadan kaybolmuştur. İlyas Çelebi, "Yıldızname", Türkiye Diyanet Vakfi İslam Ansiklopedisi, TDV Yayınları, C.43, İstanbul: 2013, s.545-547. 
Bazı rivayetlerde şehri yenileyip imar eden kişinin Haccâc'ın kardeşi değil amcası oğlu Muhammed b. Kasım Ebî Akîl olabileceği ve şehrin bulunduğu yerin aslan göğsüne benzediği için de buraya Şiraz isminin verildiği ileri sürülmüsstür9 . Fakat Zerkûb-î Şîrâzî’nin Muhammed b. Yusuf'un bu eyaletteki görevi bittikten sonra geri döndüğüne dair kayıtları şehrin kurucusunun Muhammed b. Yusuf olduğu ihtimalini daha da güçlendirmektedir. Bunun yanı sıra Zerkûb, Muhammed b. Yusuf'un valiliği sırasında iki buçuk yıl halifelik yapan Ömer b. Abdulaziz'in bu şehre çok ilgi gösterdiğini, birçok hayır binası, mescit ve diğer dini mekânların Şiraz'da inşa edilmesi için emir verdiğini kaydetmiştir ${ }^{10}$.

İbn Belhi, bu şehrin büyüklüğünün birkaç tane İsfahan kadar olduğunu ve 1.000 adımdan daha uzun ve geniş olduğunu yazmıştır ${ }^{11}$. Fehender Kalesi, antik Persapolis şehri kalıntıları ve Ebu Nasr sarayının bulunduğu yerde inşa edilen Şiraz şehri, ilk etapta Araplar tarafindan bir ordugâh olarak kullanılmıştır. Fakat ilerleyen zamanlarda bölgeye göç eden Araplar ve yerli halktan İslamiyet'i kabul edenlerin de buraya yerleşmesi ile her geçen gelişerek büyümesiyle birlikte İstahr şehrinde bulunan hükümet merkezi Şiraz'a taşınmış ve Fars illerinin idare merkezi haline gelmiş$\operatorname{tir}^{12}$.

\section{Fars Bölgesinde İktidar Mücadeleleri}

Haccâc'ın Horasan valiliğini yapan Mühelleb b. Sufra, ölmeden önce kendisinden sonra oğlu Yezid'in Horasan valisi olmasını vasiyet etmiştir. Haccâc da aynı zamanda kayınpederi olan Mühelleb'in vasiyetini yerine getirerek oğlu Yezid'i yeni vali olarak görev yapmasını onaylamış$\operatorname{tır}^{13}$. H.85/M.704 yılına kadar valilik görevine devam eden Yezid'in bu tarihten itibaren makamını kendi çıkarları için kullanması ve bölgedeki asi gruplara karşı müsamahakâr davranışları Haccâc'1 rahatsız etmiş ve halifeden onu azlederek hapse atmak için izin istemiştir ${ }^{14}$. Halife Abdülmelik' in de onayını alan Haccâc, Yezid'i Horasan valiliğinden azlederek hapse atmış ve yerine kardeşi Mufaddal'ı vekil olarak atamıştır ${ }^{15}$. Mufaddal Haccâc'ın yanındaki yerini sağlama almak için kardeşinin sessiz kaldığı isyancı gruplarla savaşmış ve Horasan'ın çeşitli bölgelerine seferler düzenleyerek elde ettiği ganimetleri de askerlerine dağıtmıştır. Fakat bütün bu çabalarına rağmen Haccâc tarafindan sadece dokuz ay görevde tutulmuş ve sonrasında azledilerek yerine Kuteybe b. Müslim $\operatorname{atanm}_{1} \operatorname{str}^{16}$.

İstahri, Mesâliku'l-Memlik Ülkelerin Yolları Değerlendirme-Metin, çev. Murat Ağarı, Ayışığı Kitapları,1. Baskı, İstanbul, 2015,s.126; Muhammed b. Ahmed el-Mukaddesi, İslam Coğrafyası (Ahsenü't-Takâsîm) Çeviri ve Notlar, Ahsen Batur, Selenge Yayınları 1. Bask1, İstanbul, 2015, s.440; İbn Havkal, 10. Asırda İslam Coğrafyası, Tercüme: Ramazan Şeşen, Yeditepe Yayınları, İstanbul, 2014, s.224; Müstevfi, Nuzhetü’l-Kulub, 114; Cl. Huart “Şiraz”, İslam Ansiklopedisi, Milli Eğitim Basımevi C.11 İstanbul, 1979, s.563.

10 Zerkûb-i Şîrâzî, Şirazname, s.24; Efser, Tarih-i Baft-ı Kadim-i Şiraz, s.38.

11 İbn Belhi, Farsname, s.132; Efser, Tarih-i Baft-l Kadim-i Şiraz, s.37.

12 Efser, Tarih-i Baft-ı Kadim-i Şiraz, s.38.

13 İbnü'l-Esir, El-Kâmil Fi't-Tarih, Çev. Abdülkerim Özaydın ve dğr., Bahar Yayınları, 1. Baskı, İstanbul, 1985, C.4, s.526-527; İbn Kesir Ebu'l-Fida, el-Bidaye ve'n-Nihaye, Çağrı Yayınları, 1. Bask1, İstanbul, 1994, C.9, s.74; Fatma Odabaş1, "Yezid b. Mühelleb", Türkiye Diyanet Vakfi İslam Ansiklopedisi, TDV Yayınları, C. 43, İstanbul, 2013, s.522.

14 İbnü'l-Esir, El-Kâmil Fi't-Tarih, C.4, s.51-452; İbn Kesir, el-Bidaye ve'n-Nihaye, C.9, s.96; Ebu Cafer Muhammed b. Cerir et-Taberi, Milletler ve Hükümdarlar Tarihi, Çev. Zakir Kadiri Ugan, Ahmet Temir, Milli Eğitim Basımevi 1. Bask1, İstanbul, 1991, C3, s.330,332-333.

15 İbnü'l-Esir, El-Kâmil Fi't-Tarih, C.4, s.52; Taberi, Tarih-i Taberi, C.3, s.333.

16 İbnü'l-Esir, El-Kâmil Fi't-Tarih, C.4, s.453-454; Taberi, Tarih-i Taberi, C.3, s.334-335; Hakk1 Dursun Y1ldız, Doğuştan 
H.90/M.708-709 yılında Fars bölgesinde Kürtlerin isyan çıkararak birçok şehrin idaresini ele geçirdikleri haberi gelmiştir. Bunun üzerine Haccâc, Fars topraklarına yapacağı seferin asker sevkiyatını düzenlemek amacıyla Rustakabaz’a giderken, yokluğundan istifade ederek kaçma teşebbüsünde bulunabileceklerini düşündüğü Yezid b. Mühelleb ve kardeşlerini de beraberinde götürmüştür. Onları kendisine yakın ve etrafı hendek kazılı bir çadırda tutan Haccâc, onların kaçmamaları için de çadırın etrafına nöbetçi dikmiştir. Bütün bu önlemlere rağmen Yezid, dört yıl boyunca çeşitli işkencelere maruz kaldığı Haccâc'ın elinden kendisine yemek getiren aşçının yardımıyla kardeşleri Mufaddal ve Abdülmelik birlikte kaçmayı başarmıştır. Haccâc'ın elinden kurtulmayı başaran Yezid, kendisi gibi Haccâc'a karşı düşmanlık besleyen ve aynı zamanda hilafet makamının da varisi olan Süleyman b. Abdülmelik'e sığınmış ve onun himayesine girmiştir ${ }^{17}$. İlerleyen yıllarda önce Haccâc'ın ardından halife Velid b. Abdülmelik'in ölmesi üzerine rahat bir nefes alan Yezid, Süleyman b. Abdülmelik'in halife olması ile birlikte Irak'a genel vali olarak tayin edilmiştir. Bir süre sonra Horasan valiliğini de elde eden Yezid, H.97/M.715 yılında Irak’tan Horasan'a giderek orda yaşamaya başlamıştır ${ }^{18}$.

Yezid, dönemin ünlü komutanlarından Kuteybe b. Müslim'in gölgesinde kalmamak adına çıktığı seferler sonucunda Cürcan ve Taberistan önemli fetihler gerçekleştirerek büyük ganimetler elde etmiştir. Fakat bu ganimetlerin dağılımı ve halifeye göndermeyi taahhüt ettiği miktarı göndermemesi üzerine halife Süleyman b. Abdülmelik ile arası açılmıştır. Süleyman b. Abdülmelik'in H.99/M.717 yılında ölümüyle birlikte halife olan Ömer b. Abdülaziz de bu durumun aydınlığa kavuşması için onu huzuruna çağırmıştır. Adeta başına geleceklerden emin olan ve ikinci bir defa hapis hayatı yaşamayı göze alamayan Yezid, Horasan'da yerine oğlu Muhalled'i birakarak önce Vasit'a ordan Basra'ya geçerek kaçma girişimde bulunmuştur. Fakat Yezid'in kaçabileceği ihtimalini düşünen halife Ömer, yeni kurulan Şiraz şehrinde ikamet eden Fars valisi Adiyy b. Ertat'a onu tutuklayarak kendisine göndermesini istemiştir. Bunun üzerine Ertat'ın bu iş için görevlendirdiği Musa b. Vecih, Yezid'i Vasıt şehrinden hareket ederek Basra'ya giden bir geminin içinde yakalayarak tutuklamış ve halifeye göndermiştir ${ }^{19}$. Bu başarısından dolayı Ömer b. Abülaziz, Adiyy b. Ertat'1 Basra valiliği görevine atamıştır ${ }^{20}$.

Daha sonra Yezid'i huzuruna getirten halife ona neden göndermeyi taahhüt ettiği ganimet miktarını göndermediğini sormuş, aldığı tutarsız cevaplar karşısında tatmin olmayan ve sinirlenen halife onu Horasan valiliğinden azlederek tutuklanıp hapse atılmasına karar vermiştir ${ }^{21}$. Bu arada Yezid'den boşalan Horasan valiliği görevine de önce Cerrah b. Abdullah Hakemi'yi atamış fakat daha sonra onu da azlederek aralarında görev paylaşımı yaptığı Abdurrahman b. Nuaym ve Abdurrahman b. Abdullah’1 Horasan bölgesinin idaresi için görevlendirmiştir²2.

Yezid b. Mühelleb'in bu ikinci tutukluluk dönemi diğerinden daha kısa sürmüştür. İki y1l

Günümüze Büyük İslam Tarihi Çă̆ Yayınları, İstanbul, 1992, C.2, s.382-383.

17 Taberi, Tarih-i Taberi, C.3,s.356-357; İbnü'l-Esir, El-Kâmil Fi't-Tarih, C.4,s.488-490; İbn Kesir, el-Bidaye ve'n-Nihaye, C.9, s.132.

18 İbnü'l-Esir, El-Kâmil Fi't-Tarih, C.5, s.27-29; İbn Kesir, el-Bidaye ve'n-Nihaye, C.9, s.274; Odabaş1, "Yezid b. Mühelleb”, C.43, s.522.

19 Taberi, Tarih-i Taberi, 3:396; İbnü'l-Esir, El-Kâmil Fi't-Tarih, C.5, s.49-50; İbn Kesir, el-Bidaye ve'n-Nihaye, 9:304; Odabaş1, "Yezid b. Mühelleb", C.43, s.522.

20 İbn Kesir, el-Bidaye ve'n-Nihaye, C.9, s.299; Odabaş1, "Yezid b. Mühelleb”, C.43, s.522.

21 Taberi, Tarih-i Taberi, C.3, s.396-397; İbnü'l-Esir, El-Kâmil Fi't-Tarih, C.5, s.49-50; İbn Kesir, el-Bidaye ve'n-Nihaye, C.9, s.305; Odabaş1, "Yezid b. Mühelleb”, C.43, s.522.

22 İbnü'l-Esir, El-Kâmil Fi't-Tarih, C.5, s.51-53; İbn Kesir, el-Bidaye ve'n-Nihaye, C.9, s.305; Taberi, Tarih-i Taberi, C.3, s.396. 
hapiste kalan Yezid, halife Ömer b. Abdülaziz'in ölüm döşeğinde olduğunu ve onun yerine Yezid b. Abdülmelik' in halife olacağını öğrenince hapisten kaçmak için harekete geçmiştir. Çünkü vaktiyle Yezid b. Abdülmelik'in hısımları olan Ebi Akîloğulları kabilesine işkence etmişstir. Haccâc b. Yusuf' un kardeşinin kızıyla evlenerek bu kabile ile hısım olması Yezid b. Abdülmelik'in kendisini işkence ile öldürmesinden korkmuştur. Yezid b. Mühelleb, Ömer b. Abdülaziz'in hastalığ1 ilerleyince azatlı kölelerine haber yollayarak hapisten kaçması için kendisine yardımcı olmalarını istemiştir ${ }^{23}$. Hapisten kaçmayı başaran Mühelleb'in Ezd ve Rebia kabilelerinden topladığ destek kuvvetlerle beraber Basra'ya doğru harekete geçtiğini öğrenen yeni halife Yezid b. Abdülmelik, Basra valisi Adiyy b. Ertat'a haber göndererek durumdan haberdar etmiş ve gerekli tedbirleri almasını söylemiştir. Ayrıca Mühelleb'in çocukları ve akrabalarının yakalanarak hapse atılmasını emretmiştir. Bunun üzerine vali Ertat, başta Mühelleb'in oğulları Mufaddal, Habib ve Mervan olmak üzere onun bütün akrabalarını yakalayarak hapsetmiştir. Ayrıca Basra'nın dört bir yanına elçiler göndererek ileri gelen Arap kabilelerinden Yezid b. Mühelleb'e karşı kendisine destek vermesini istemiştir. Fakat bu kabilelerden sadece Temim ve Kays kabilesi olumlu yanıt vermiştir. Etrafına topladığı kabilelerin desteğiyle vali Ertat'1 etkisiz hale getirerek Basra'yı ele geçiren Mühelleb, başlatmış olduğu isyan hareketini dini bir çerçeveye sokmak ve dindar kesimin desteğini kendi yanına çekebilmek için halkı Kur'an ve sünnete uyarak cihad etmeye çağırmıştır ${ }^{24}$. Mühelleb, Basra'yı ele geçirip vali Ertat'1 hapse attıktan sonra Beytülmalin içerisindeki bütün parayı askerlere dağıtılmasına karar vermiştir ${ }^{25}$. Bunun etkisiyle kısa süre sonra mevalinin de onun saflarına katılmasıla birlikte Basra'ya bağlı Ahvaz, Fars, Kirman ve Sind bölgesi halkları ona bağlılıklarını bildirmiştir. Yezid bu bölgelerden gelen çok sayıdaki askeri güçle birlikte Basra'yı tamamen kendi kontrolüne almıştır ${ }^{26}$.

Basra'yı ele geçirdikten sonra yerine kardeşi Mervan’ı bırakarak Vasıt şehrine yönelmiştir. Vasıt şehrini de ele geçiren Mühelleb kardeşi Habib diğer yakın arkadaşlarının Fars bölgesinde çekilip konaklayarak önemli geçitleri ve tepeleri kontrol altına alarak önce Horasan'a oradan da Şam ehline ulaşma fikrini kabul etmeyerek Kûfe'ye Yezid b. Abdülmelik'in üzerine yönelme konusunda 1srarcı ve aceleci olmuştur ${ }^{27}$. Vasit şehrine oğlu Muâviyeyi vekil birakarak Kûfe'ye doğru yola çıkan Mühelleb’i halifenin kardeşi Mesleme b. Abdülmelik ve kardeşinin oğlu Abbas b. Velid b. Abdülmelik karşılamış ve iki taraf arasında çok şiddetli çarpışmalar meydana gelmiştir. Mühelleb, her ne kadar Emevi ordusunda yer alan Ezd, Rebia ve Temim kabilesine mensup kişileri kendi tarafına çekmeyi başarmış olsa dahi Abbas ve Mesleme'nin askerlerine karşı varlık gösteremeyerek bozguna uğramıştır. Ordusu dağılarak dört bir tarafa kaçan Mühelleb, kardeşi ve kendisine yakın olan arkadaşları ile beraber ölene kadar savaşmaya devam etmiştir ${ }^{28}$. Mühelleb'in ölüm haberi Vasıt'a gelince Muâviye babası tarafından hapse atılan başata Adiyy b. Ertat ve ço-

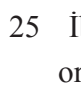
orduya katılan herkese altın ve gümüş dağıtmasının önemli bir faktör olduğunu kaydetmiştir. Buna rağmen Adiyy b. Ertat’ın ise
sadece 2 dirhem vermesi daha fazlasının halifenin emri olmadan veremeyeceğini açıklaması üzerine Basra ve ona bağlı diğer şehirlerdeki halkın çoğu tercihini Mühelleb'den yana yapmıştır. İbnü'l-Esir, El-Kâmil Fi't-Tarih, C.5, s67-68.

26 Taberi, Tarih-i Taberi, C.3, s.403; Y1ldı, Doğuştan Günümüze Büyük İslam Tarihi, C.2, s.414-415; Odabaş1, "Yezid b. Mühelleb", C.43, s.522.

27 İbnü'l-Esir, El-Kâmil Fi't-Tarih, 5:71; Taberi, Tarih-i Taberi, 3:404.

28 Hamdullah Müstevfi-i Kazvinî, Tarih-i Güzide, Neşr. Abdu'l-Hüseyin Nevaî, Emir Kebir Yayınları, Tahran, 1339, s.282; İbnü'l-Esir, El-Kâmil Fi't-Tarih, C.5, s.72; İbn Kesir, el-Bidaye ve'n-Nihaye, C.9, s.357; Taberi, Tarih-i Taberi, C.3, s.404-405; Yıldız, Doğuştan Günümüze Büyük İslam Tarihi, C.2, s.415; Odabaş1, "Yezid b. Mühelleb”, C.43, s.522. 
cukları olmak üzere 32 kişiyi idam etmiştir ${ }^{29}$. Mühelleb'in ölümüyle birlikte kardeşleri ve çocukları başta olmak üzere ailesinin geri kalanları devlet hazinlerini de yanlarına alarak önce Fars'a oradan da Kirman'a kaçmak istemişlerse de Halife Yezid b. Abdülmelik, onları yakalamayı başarmış ve ailesinin büyük bir kısmını ettirmiş geri kalanı da tutuklayarak hapse attırmıştır. Ayrıca halifenin emri ile Mühellebiler ailesinin bütün mallarına el konularak kadın ve çocukları köle olarak pazarlarda satılmıştır ${ }^{30}$.

Mesleme b. Abdülmelik, Yezid b. Mühelleb ile olan savaşını bitirdikten sonra halife olan kardeşi Yezid b. Abülmelik tarafindan Fars bölgesinin bağlı olduğu Basra, Kûfe ve Horasan'ın idaresi kedisine verilerek Irak genel valiliği görevine getirilmiştir. Horasan'da damadını naib olarak atayan Mesleme, Kûfe ve Basra'ya da naibler göndererek Mühellebiler ailesi adına hüküm sürmeye çalışanların cezalandırılmasını sağlamış ve buralarda devlet otoritesini yeniden tahsis etmeye çalışmıştır. Aldığı tedbirler sayesinde Mühellebiler'in sebep olduğu kargaşa ortamının ortadan kalkması ve istikrarın tekrar sağlanması yolunda önemli adımlar atılmıştır. Fakat kısa bir süre sonra idaresi altındaki şehirlerin devlet hazinelerini hilafet merkezine göndermediği gerekçesi ile H.102/M.720-721 yılında Irak genel valiliği görevinden azledilmiştir ${ }^{31}$.

\section{Emevilerin Son Zamanlarında Fars Bölgesi ve Şiraz}

H.105/M.724 y1lına gelindiğinde vefat eden Yezid b. Abdülmelik'in yerine halife olan kardeşi Hişam b. Abdülmelik, özellikle Basra ve Fars bölgelerindeki Kays kabilesinin baskısını ortadan kaldırmak ve olası kabile savaşlarına engel olmak adına Ömer b. Hübeyre’yi azlederek Halid b. Abdullah el-Kasrî’yi Irak'a genel vali olarak atamıştır ${ }^{32}$. Halid, özellikle Basra ve Fars bölgeleri başta olmak üzere bütün Irak bölgesini Ziyad ve Haccâc'in zamanındaki gibi sükûnete kavuşturmaya çalışmış bunu bir noktaya kadar da başarmıştır. Fakat bir süre sonra aldığı bütün tedbirlere rağmen kendisini bölgedeki kabilelerin iktidar mücadelesi içerisinde bulmuş ve kendisinin de mensubu olduğu Yemenli Kays kabilesinin tarafını tutmaya mecbur kalmıştır. Ziraata büyük önem veren Halid Irak topraklarının birçok yerinde bataklıkları kurutarak sulama kanalları açmış bu sayede zirai gelirlerde büyük bir artışın olmasını sağlamıştır. Fakat bu gelirlerin kendisine alması, ona muhalif olanların Hristiyan ve Yahudi halkı korumakla suçlamaları sonucunda devlet içerisinde ona karşı bir grubun oluşmasına yol açmıştır. Bütün bunlar sonucunda H.120/M.738 yılında yaklaşık on beş yıl yürüttüğü valilik görevinden azledilmiştir ${ }^{33}$.

Halid b. Abdullah azledildikten sonra onun yerine Haccâc'ın amcasının torunu Yusufb. Ömer es-Sekafî getirilmiştir. Yusuf b. Ömer, göreve başladıktan Halid b. Ömer ve oğullarını tutuklayarak hapse atmıştır. On sekiz ay tutuklu kalan Halid ve oğulları Hişam b. Abdülmelik öldükten sonra serbest bırakılmış fakat yeni halife II. Velid onu tekrar tutuklatmış ve Yusuf b. Ömer'e göndermiş523.

3

32 Íslam Tarihi, C.2, s.418; Abdülkerim Özaydın, "Halid b. Abdullah el-Kasrî”, Türkiye Diyanet Vakfi İslam Ansiklopedisi, TDV Yayınlar1, C.15, İstanbul, 1997, s.281-282.

33 İbnü'l-Esir, El-Kâmil Fi 't-Tarih, C.5, s.181-182; İbn Kesir, el-Bidaye ve'n-Nihaye C.9, s.532-533; Y1ldı, Doğuştan Günümüze Büyük İslam Tarihi, C.2, s.418; Özaydın, "Halid b. Abdullah el-Kasrî”, C.15, s.282; İsmail Hakkı Atçeken, "Yusuf b. Ömer es-Sekafi”” Türkiye Diyanet Vakfi İslam Ansiklopedisi, TDV Yayınlar1, C. 44, İstanbul, 2013, s.22. 
tir. Bir süre daha hapis hayatı yaşayan Halid daha sonra işkence edilerek öldürülmüştür ${ }^{34}$. Yusuf b. Ömer' in valiliği döneminde Irak topraklarında Halid zamanında sağlanan istikrar ve sükûnet ortamı son bulmuş ve Yemeni-Kaysi kabile düşmanlığı tekrar orta çıkmıştır. Yusuf b. Ömer'in bu durum karşısında sert ve acımasız tutumu muhalif grupları harekete geçirmiş ve Emeviler tarihinin en önemli isyanlarından birinin ortaya çıkmasına sebep olmuştur. Hz. Ali soyundan gelen Zeyd b. Ali b. Hüseyin b. Ali, Şii grupları yanına çekmeye çalışarak giriştiği bu isyan hareketi Yusuf b. Ömer'in Şam askerleri ile birlikte yaptığı ani bir baskın ile Zeyd b. Ali ve taraftarlarının tamamının öldürülmesi ile sonuçlanmıştır ${ }^{35}$.

Yusuf b. Ömer'in sert ve acımasız tutumu Hişam b. Abdülmelik'in H.125/M.743 yılında ölmesi üzerine halife olan II. Velid yani Velid b. Yezid b. Abdülmelik döneminde de devam etmiştir. Halid b. Abdullah'ın öldürülmesi ile birlikte Yemenli kabileler üzerine uygulamaya başladığı baskı politikası onların Velid'e düşman olmasına sebep olmuştur. Bir süre sonra hanedan üyelerinin de Velid'e karşı cephe almasıyla birlikte Emevi devletini yok olma sürecine sokacak bir isyan hareketi başlamıştır. III. Yezid ${ }^{36}$ olarak bilinen Yezid b. Velid b. Abdülmelik'in etrafına toplanan hanedan üyeleri H.126/M.744 yılında başlattıkları isyanla sarayı basarak Velid'i öldürerek III. Yezid'i halife ilan etmiştir ${ }^{37}$. III. Yezidaltı ay iki günlük halifelik yaptıktan sonra H.126/M.744 yılında yakalandığı ağır hastalıktan kurtulamayarak vefat etmiş ve onun yerine kardeşi İbrahim b. Velid b. Abdülmelik halife olmuştur ${ }^{38}$. Fakat onun halifeliği de sadece iki ay kadar sürmüştür. İbrahim b. Velid'in halife olduğu haberini alan II. Mervan olarak bilinen Mervan b. Muhammed b. Mervan b. Hakem, Kays kabilesinden topladı̆̆ 1 askerleri ile birlikte yola çıkarak Şam’a gitmiştir. İbrahim b. Velid ve Şam askerlerinin büyük kısmının kaçması üzerine Mervan halifeliğini ilan etmiştir ${ }^{39}$.

Mervan'1n halifeliğini ilan ettiği zamanlarda Abdullah b. Muâviye b. Abdullah b. Cafer b. Tayyar b. Ebi Talib ${ }^{40}$ Medine'den Kûfe'ye gelerek buraya yerleşmiştir. Kûfe'de bulunan Irak valisi Abdullah b. Ömer b. Abdülaziz tarafından İbrahim b. Velid ile Mervan arasındaki halifelik mücadelesi sırasında tedbiren hapse atılmıştır. Bir süre hapiste kaldıktan sonra serbest kalan Abdullah $b$. Muâviye Kûfe Şiilerinin desteğini alarak isyan çıkarmıştır. Kısa sürede kalabalık bir grubu etrafın-

34 İbnü'l-Esir, El-Kâmil Fi't-Tarih, C.5, s.231; İbn Kesir, el-Bidaye ve’n-Nihaye, C.10, s.23; Özaydın, "Halid b. Abdullah elKasrî”, C.15, s.282; Atçeken, "Yusuf b. Ömer es-Sekafî", C.44, s.22.

35 İbnü'l-Esir, El-Kâmil Fi't-Tarih, C.5, s.202vd.; Taberi, Tarih-i Taberi, C.3, s.427-431; İbn Kesir, el-Bidaye ve'n-Nihaye, C.9, s.534-535; Atçeken, "Yusuf b. Ömer es-Sekafî", C.44, s.22.

36 III. Yezid yani Yezid b. Velid b. Abdülmelik b. Mervan'ın annesi nakledilenlere göre Fars asıllı bir cariye olan Şâhferend binti Feyruz b. Yezdicerd b. Şehriyâr b. Kisradır. Yezid'in bu konu hakkında dedelerinden birinin Kayser birinin de Türk Hakanlarından biri olduğunu söylemiştir. Kuteybe b. Müslim, Annesi Şâhferend ile kız kardeşini çıkmış olduğu bir gazada esir alarak Şâhferend'i halife Velid'e göndermiş, kız kardeşini ise kendi yanında tutmuştu. İbnü'l-Esir, El-Kâmil Fi't-Tarih, C.5, s.259; İbn Kesir, el-Bidaye ve'n-Nihaye, C.10, s.36; Mevlüd Koyuncu, "Yezid III", Türkiye Diyanet Vakfi Islam Ansiklopedisi, TDV Yayınları, C. 43, İstanbul, 2013, s.516.

37 İbn Kesir, el-Bidaye ve'n-Nihaye, C.10, s.36; İbnü'l-Esir, El-Kâmil Fi't-Tarih, C.5, s.241; Taberi, Tarih-i Taberi, C.3, s.435; Y1ldız, Doğuştan Günümüze Büyük İslam Tarihi, C.2, s.428-429.

38 İbnü'l-Esir, El-Kâmil Fi't-Tarih, C.5, s.259-260; İbn Kesir, el-Bidaye ve'n-Nihaye, C.10, s.237; Taberi, Tarih-i Taberi, C.3, s.435; Julius Wellhausen, Arap Devleti ve Sukutu, Terc. Fikret Işıltan, Ankara Üniversitesi İlahiyat Fakültesi Yayınları, 1. Bask1, Ankara, 1963, s.178; Koyuncu, "Yezid III", C.43, s.517.

39 İbnü'l-Esir, El-Kâmil Fi't-Tarih, C.5, s.268-269; Taberi, Tarih-i Taberi, C.3, s.435-436; İbn Kesir, el-Bidaye ve'n-Nihaye, C.10, s.47; Hasan Kurt, "Mervan II”, Türkiye Diyanet Vakfi İslam Ansiklopedisi, TDV Yayınları, C.29, İstanbul, 2004, s.227.

40 Mûte Savaşı'ndaki fedakârlığından dolayı Hz. Peygamber tarafından Zü'l-cenahayn lakabı verilen Ca'fer-i Tayyar'ın bu lakabına nispetle, Abdullah b. Muaviye'nin etrafında toplanan ve onu imam olarak tanıyan gruba Cenahiyye denilmiştir. Ethem Ruhi Fığlalı, "Abdullah b. Muaviye”, Türkiye Diyanet Vakfi İslam Ansiklopedisi, TDV Yayınları, C.1, İstanbul, 1988, s.119. 
da toplayarak Fars bölgesine doğru yola çıkmış ve Sasaniler'e uzun süre başkentlik yapan Medain şehrinde konaklamıştır. Burada kendisine katılan Kûfeliler ve diğer şehirlerden gelenlerle birlikte sayıları daha da artmıştır. Destekçileri ile birlikte Fars bölgesine giren Abdullah b. Muâviye, önce İsfahan ardından Cibal, Huzistan Hûlvan, Kumis ve Rey şehirlerini ele geçirerek Irak valisi Abdullah b. Ömer'in bu şehirlere görevlendirdiği idarecileri de şehirden kovmuştur ${ }^{41}$.

Benû Yeşkür kabilesine mensup azatlı bir köle olan Muharib b. Musa, Abdullah b. Muaviye adına çıktığı seferlerde ilk olarak İstahr şehrine giderek şehri ele geçirdikten sonra beraberindeki Şamlı komutanlarla birlikte Kirman'a yağma seferlerine çıkmıştır. Daha sonra H.128/M.747 yılında Şiraz şehrine gelen Musa burada Abdullah b. Ömer'in naibliğini yapan Müslim b. Müseyyeb’i öldürerek Şiraz'1 kendi idaresine almıştır. İstahr ve Şiraz halkının Abdullah b. Muâviye’ye biat etmesini sağladıktan sonra İsfahan'a Abdullah b. Muâviye'nin yanına dönen Musa, Abdullah b. Muaviye'nin İstahr'a gitmesi ve oraya yerleşmesi konusunda tavsiyelerde bulunmuştur. Kendisi de onunla birlikte İstahr'a yerleşmiş fakat bir süre sonra Abdullah b. Muâviye ile araları bozulunca İstahr'dan ayrılmak zorunda kalmıştır. Topladığg ordu ile birlikte Sabur'da Abdullah b. Muâviye'nin kardeşi Yezid ile savaşmış ve bu savaşı kaybedince de Kirman'a çekilmek zorunda kalmıştır ${ }^{42}$.

Mervan halifeliğini sağlama alıp idareyi tamamen kendi eline aldıktan sonra Şam ordusunda görev yapan kumandanlarından Amir b. Dubara'yı Davud b. Yezid b. Ömer b. Hübeyre ile birlikte İstahr'a Abdullah b. Muâviye'nin üzerine gönderdi. İbn Hübeyre öncü kuvvet olarak Şiraz'ın tanınmış şahsiyetlerinden olan Ma'n b. Zaide b. Abdullah'1 Abdullah b. Muâviye üzerine göndermiştir. Merv-i Şazan bölgesinde yapılan savaşı kaybeden Abdullah b. Muâviye'nin ordusu dağılarak büyük bir kısmı esir düşmüştür. İbn Dubara bu esirlerden Abbasi ailesi taraftarı olan Abdullah b. Ali b. Abdullah b. Abbas hariç büyük bir bölümünü idam etmiş, Abdullah b. Ali'yi ise İbn Hübeyre'ye yollayarak ve kendisi de Abdullah b. Muâviye'yi bulmak için Şiraz'a doğru yola çıkmıştır. Abdullah b. Muâviye'nin İbn Dubara'ya karşı savaşı kaybederek ordusunun dağılması üzerine Abdullah b. Muâviye'ye destek veren diğer gruplar da dağılarak çareyi başka şehirlere kaçmakta bulmuşlardır. Bunlardan Mansur b. Cumhur Sind'e, Abdurrahman b. Yezid Umman'a, Amr b. Sehl b. Abdülaziz b. Mervan Mısır'a kaçmışlardır. İbn Dubara Abdullah b. Muâviye'yi Şiraz'da sıkıştırmış fakat yakalayamamıştır. Abdullah b. Muaviye kardeşleri Yezid ve Hasan ile birlikte güvendiği adamlardan bir bölümünü yanına alarak önce Kirman’a oradan da Sicistan üzerinden Herat'a giderek Horasan'da Ebu Müslim Horasanî’ye sığınmak istemiştir. Fakat Ebu Müslim Horasanî'nin Herat emiri tarafından tutuklanmış ve Ebu Müslim Horasanî’nin emri ile öldürülmüştür ${ }^{43}$.

41 İbnü'l-Esir, El-Kâmil Fi't-Tarih, C.5, s.272-273; İbn Kesir, el-Bidaye ve'n-Nihaye, C.10, s.52,64; Halife b. Hayyat, Tarih-u Halife b. Hayyat- Halife b. Hayyat Tarihi, Çev. Abdulhalik Bakır, Bizinm Büro Yayınevi,1. Bask1, Ankara, 2001, s.449-450; Julius Wellhausen, Íslamiyet'in Illk Devrinde Dini-Siyasi-Muhalefet Partileri, Terc. Fikret Işıltan, Türk Tarih Kurumu Yayınları, 1. Bask1, Ankara, 1989, s.161-162; Wellhausen, Arap Devleti ve Sukutu, 182-183; Fiğlalı, “Abdullah b. Muâviye”,C.1, s.119.

42 İbnü'l-Esir, El-Kâmil Fi't-Tarih, C.5, s.307; Wellhausen, Arap Devleti ve Sukutu, s.183.

43 İbnü'l-Esir, El-Kâmil Fi't-Tarih, C.5, s.308; Wellhausen, İslamiyet'in Illk Devrinde Dini-Siyasi-Muhalefet Partileri, s.162; Mustafa Atalan, "Bir Muhalefet İttifak1, Abdullah b. Muâviye (129/746-47) Hareketi”, D.E.Ü İlahiyat Fakültesi Dergisi, S.XXIII, İzmir, 2006, s.42; F1ğlalı, “Abdullah b. Muâviye”,C.1, s.119. 


\section{Sonuç}

Fars bölgesinin idare merkezi olma özelliğini devam ettiren Şiraz şehrinin kuruluşundan itibaren yaklaşık iki yüz yıllık zamanı hakkında kayıtlara geçen çok az bilgi yer almıştır. Bu bilgiler de daha çok Emevi ve Abbasi halifeleri tarafindan bölgenin idaresi için görevlendirilen valiler hakkındadır. Bununla birlikte Muhammed b. Yusuf es-Sekafî'nin H.74/M.693 yılında kurmuş olduğu Şiraz şehri Emeviler devletinin yıkıldığı H.132/M.749 yılına kadar Fars topraklarının idare merkezi olmuştur. Emevi halifeleri tarafından Basra vilayetinin idaresi için görevlendirilen valiler vasıtasıyla idare edilen Fars bölgesi ve Şiraz şehri, kuruluşundan itibaren hızla gelişerek toplumun her sınıfından insanların ilgi gösterdiği bir yaşam merkezi haline gelmiştir ${ }^{44}$.

\section{Kaynakça}

Apak, Adem: Ana hatlarlyla Íslam Tarihi (3) (Emeviler Dönemi), Ensar Yayınları, İstanbul, 2010.

Atalan, Mustafa, "Bir Muhalefet İttifak1, Abdullah b. Muâviye (129/746-47) Hareketi", D.E.Ü İlahiyat Fakültesi Dergisi, XXIII (2006), 41-63.

Atçeken, İsmail Hakk1 "Yusufb. Ömer es-Sekafî" Türkiye Diyanet Vakfı Íslam Ansiklopedisi, TDV Yayınları, C. 44, İstanbul, 2013, s.22-23.

Athamına, Khalil, "Emevi Hilafeti Döneminde Arap İskânı”, Çev. Saim Yılmaz, Sakarya Üniversitesi İlahiyat Fakültesi Dergisi, S.2, Sakarya 2000, s.203-226.

Çelebi, İlyas, "Yıldıname", Türkiye Diyanet Vakfi İslam Ansiklopedisi, TDV Yayınları, C.43, İstanbul: 2013, s.545-547.

Ebu'l Abbas Ahmed b. Ebi’l-Hayr Zerkûb-i Şîrâzî, Şirazname, Nşr. Behmen Kerimi Tahran, 1305-1310.

Efser, Kerametullah Tarih-i Baft-ı Kadim-i Şiraz, İntişarat-1 Encümen-i Asar ve Mefahir-i Ferhengi Yayınları, Tahran, 1353.

el-Mukaddesi, Muhammed b. Ahmed İslam Coğrafyası (Ahsenü't-Takâsîm) Çeviri ve Notlar, Ahsen Batur, Selenge Yayınları 1. Bask1, İstanbul, 2015.

et-Taberi, Ebu Cafer Muhammed b. Cerir, Milletler ve Hükümdarlar Tarihi, Çev. Zakir Kadiri, Ugan, Ahmet Temir, Milli Eğitim Basımevi 1. Baskı, İstanbul, 1991.

Fı̆̆lalı, Ethem Ruhi, "Abdullah b. Muaviye", Türkiye Diyanet Vakf İslam Ansiklopedisi, TDV Yayınları, C.1, İstanbul, 1988, s.118-119

Halife b. Hayyat, Tarih-u Halife b. Hayyat-Halife b. Hayyat Tarihi, Çev. Abdulhalik Bakır, Bizinm Büro Yayınevi,1. Bask1, Ankara, 2001.

Hekikat, Abdu'r-Refi, Ferheng-i Tarih ve Coğrafya-yı Şehristanha-yı Iran, Tahran, 1376.

Huart, Cl., "Şiraz”, İslam Ansiklopedisi, Milli Eğitim Basımevi C.11 İstanbul, 1979, s.563564.

İbn Belhi, Farsname, Edited by G. Le Strange, R. A. Nicholson Cambridge University Press, London, 1921. 
İbn Havkal, 10. Asırda İslam Coğrafyası, Tercüme: Ramazan Şeşen, Yeditepe Yayınları, İstanbul, 2014.

İbnü'l-Esir, El-Kâmil Fi’t-Tarih, Çev. Abdülkerim Özaydın ve dğr., Bahar Yayınları, 1. Bask1, İstanbul, 1985.

İbn Kesir Ebu'l-Fida, el-Bidaye ve’n-Nihaye, Çağrı Yayınları, 1. Baskı, İstanbul, 1994.

İstahri, Mesâliku'l-Memlik Ülkelerin Yolları Değerlendirme-Metin, çev. Murat Ağarı, Ayışı̆̆1 Kitapları,1. Bask1, İstanbul, 2015.

Keyhan, Mesud Cografyâ-yı Mufassal-ı Îrân, Tahran, 1311.

Koyuncu, Mevlüd, "Yezid III", Türkiye Diyanet Vakfi İslam Ansiklopedisi, TDV Yayınları, C.43, İstanbul, 2013, s.516-517.

Kurt, Hasan, "Mervan II", Türkiye Diyanet Vakfi Islam Ansiklopedisi, TDV Yayınları C.29, İstanbul, 2004), s227-229.

Limbert, John, Shiraz In The Age Of Hafez The Glory Of A Medieval Persian City, Universiy of Washington Press, Seattle, 2004.

Müstevfi-i Kazvinî, Hamdullah, Nuzhetü'l-Kulub, Edited by G. Le Strange, Cambridge University Press, London, 1915

Müstevfi-i Kazvinî, Hamdullah, Tarih-i Güzide, Neşr. Abdu'l-Hüseyin Nevaî, Emir Kebir Yayınları, Tahran, 1339.

Odabaş1, Fatma, "Yezid b. Mühelleb", Türkiye Diyanet Vakfi İslam Ansiklopedisi, TDV Yayınlar1, C. 43, İstanbul, 2013, s.522-523.

Özaydın, Abdülkerim, "Halid b. Abdullah el-Kasrî", Türkiye Diyanet Vakfi İslam Ansiklopedisi, TDV Yayınları, İstanbul, 1997, C.15, s.281-282.

Özgüdenli, Osman Gazi, "Şiraz”, Türkiye Diyanet Vakfi İslam Ansiklopedisi, TDV Yayınları, C.39, İstanbul, 2010, s.182-184.

Strange, Guy Le, Doğu Hilafetinin Memleketleri (Mezopotamya, Iran ve Orta Asya) İslam Fetihlerinden Timur Zamanına Kadar, Terc. Adnan Ekikurt, Cengiz Tomar, Yeditepe Yayınları, İstanbul, 2015.

Terzi, Mustafa Zeki, "Emevîlerde Kara Ordusu Teşkilâtı”, Ondokuz Mayıs Üniversitesi Ilahiyat Fakültesi Dergisi, S.9, Samsun 1997, s.41-88.

Wellhausen, Julius, Arap Devleti ve Sukutu, Terc. Fikret Iş1ltan, Ankara Üniversitesi İlahiyat Fakültesi Yayınları, 1. Bask1, Ankara, 1963.

Wellhausen, Julius, İslamiyet'in Illk Devrinde Dini-Siyasi- Muhalefet Partileri, Terc. Fikret Işıltan, Türk Tarih Kurumu Yayınları, 1. Baskı, Ankara, 1989. 1992.

Yıldız, Hakkı Dursun, Doğuştan Günümüze Büyük İslam Tarihi C.2, Çağ Yayınları, İstanbul,

Yiğit, İsmail, “Emeviler”, Türkiye Diyanet Vakfi İslam Ansiklopedisi, TDV Yayınları, C.11, İstanbul, 1995, s.87-104. 